W H I S P E R I N G C I T Y 



\section{WHISPERING CITY}

米

MODERN ROME AND ITS HISTORIES

R.J.B. BOSWORTH 
Copyright () 2011 R.J.B. Bosworth

All rights reserved. This book may not be reproduced in whole or in part, in any form (beyond that copying permitted by Sections 107 and 108 of the U.S. Copyright Law and except by reviewers for the public press) without written permission from the publishers.

For information about this and other Yale University Press publications, please contact: U.S. Office: sales.press@yale.edu www.yalebooks.com Europe Office: sales@yaleup.co.uk www.yaleup.co.uk

Set in Minion Pro by IDSUK (DataConnection) Ltd Printed in Great Britain by TJ International Ltd, Padstow, Cornwall

Library of Congress Cataloging-in-Publication Data

Bosworth, R.J.B.

Whispering city : modern Rome and its histories/R.J.B. Bosworth. p. cm.

Includes bibliographical references.

ISBN 978-0-300-11471-3 (cloth:alk. paper)

1. Rome (Italy)-History. 2. Rome (Italy)-Historiography.

3. Memory-Social aspects-Italy-Rome. 4. Historic sites-Italy-Rome.

5. Historic buildings-Italy-Rome. 6. Architecture-Italy-Rome. 7. Rome (Italy)-Description and travel. 8. Rome (Italy)-Buildings, structures, etc. I. Title.

DG809.B67 2011

945'.632-dc22

A catalogue record for this book is available from the British Library. 
For Edmund, Mary and their Romes 
Today the age

Of the private patron is over; Maecenas and Co.

Have no successors....

What about writers of history? Do all their labours

Bring them a bigger return or merely consume

More midnight oil? With unrestricted licence

They pile up their thousand pages - and an enormous

Stationery bill: the vast extent of the theme,

Plus their professional conscience, makes this inevitable.

But what will the harvest yield, what fruit will all your grubbing

Bring you? Does any historian pull down a newsreader's wage?

Juvenal, The sixteen satires (Harmondsworth: Penguin, 1974), p. 166.

Rome 'is not simply a collection of dwellings; it is the history of the world, represented by different symbols and portrayed in different forms.

G. de Stael, Corinne or Italy (ed. S. Raphael), Oxford University Press, 1998), p. 82. 